\title{
Migration Workers as Political Subjects: Globalization-as-Practices, Everyday Spaces, and Global Labour Migrations
}

\author{
HiRONORI ONUKI
}

\section{Abstract}

Within the currently intensified labour flows from developing societies to highly industrialized areas, the Philippines has been the largest supplier of government-sponsored contract workers. Overseas contract employment was institutionalized by the Philippine government in 1972 to tackle the problems of unemployment and foreign debt. The remittances from migrant workers have become a major source of foreign currency for the national economy, which led the then president Aquino to call overseas workers "national heroes." In this light, building upon Louise Amoore's conceptualization of globalization as sets of globalizing social practices, my essay will investigate the concrete, contingen, t and situated practices of global labour migration. By so doing this analysis will stress that these migrant workers are not passive recipients of Philippine state policies but are agential political subjects. It will argue that the structured social practices of global labour migrants not only participate in and depend on, but also contest and negotiate, the (re)constitution of capitalist relations of production and social reproduction within the neo-liberal restructuring of global order. The objective of my essay is to contribute towards both the illustration of global politics as social relations produced by various actors in multiple spheres and emergent crucial efforts to pursue the possibilities for an emancipatory project and political resistance.

\section{Résumé}

Dans le contexte des flux de travailleurs - flux actuellement intensifiés - allant des sociétés en développement vers des zones hautement industrialisées, les Philippines a été le plus grand pourvoyeur de travailleurs-sous-contrat parrainés par un gouvernement. L'emploi à l'étranger sous contrat a été institutionnalisé par le gouvernement philippin en 1972 comme mesure pour régler les problèmes du chômage et de la dette extérieure. Les envois de fonds des travailleurs expatriés sont devenus une source importante de devise étrangère pour l'économie nationale, ce qui avait amené la Présidente Aquino, présidente à l'époque, à qualifier les ouvriers expatriés de "héros nationaux". Dans cette optique, et en élaborant sur le modèle de Louise Amoore qui a conceptualisé la globalisation comme étant des ensembles de pratiques sociales globalisantes, mon essai examinera les pratiques concrètes, contingentes et localisées de la migration globale de travailleurs. Ce faisant, cette analyse soulignera le fait que ces travailleurs migrants ne sont pas les bénéficiaires passifs de la politique de l'état philippin, mais sont en fait des acteurs politiques. Elle soutiendra que les pratiques sociales structurées des travailleurs immigrants à l'échelle globale, non seulement participent à, et dépendent de, la reconstitution des rapports de production capitalistes et de reproduction sociale dans la restructuration néolibérale de l'ordre mondial, mais qu'elles remettent en question et négocient ces mêmes rapports. L'objectif de mon essai est, d'une part, de concourir à illustrer la politique globale en tant que relations sociales produites par divers acteurs dans des sphères multiples, et de l'autre, de contribuer aux efforts décisifs émergents pour examiner les possibilités d'un projet émancipateur et une résistance politique. 
... what we call globalisation is best understood as representative of sets of complex and often contradictory globalising social practices.

- Louise Amoore ${ }^{1}$

? he rapidly deepening penetration of liberal market discipline into political, social, and cultural realms has become fundamentally and contradictorily associated with the reconfigurations of the global division of labour as well as with the intensification of exploitation, alienation, and commodification of human beings and nature. Within such a context, usually labelled as "globalization," the literature that attempts to conceptualize social and political relations on the global scale has been voluminous in the fields of International Relations (IR) and International Political Economy (IPE). Yet, largely due to these disciplines' preoccupation with the emergence of the modern nation-state and to the rise of the bourgeoisie as a dominant social class through the consolidation of capitalist economy, IR and IPE scholars predominantly tend to focus on elite forms of transnational, state, or corporate agents with direct, top-down decision making and thus distance global politics from contextualized experiences. ${ }^{2}$ In this respect, the objective of this essay is not to depict international relations "from the bottom up" by advocating the ambiguous notion of "global civil society,"3 but rather to unpack the linkages between global politics and individuals' everyday spaces by deeming global politics to be "social relations produced by a broad array of actors in multiple spheres." 4 To do so it will investigate the concrete, contingent, and situated practices of global labour migration and eventually contribute towards emergent crucial efforts to pursue the possibilities for an emancipatory project and political resistance. ${ }^{5}$ In particular, building upon Louise Amoore's conceptualization of globalization as sets of globalizing social practices, this essay will explore: how and with what consequences are migrant workers, as active participants, contradictorily/paradoxically complicit and yet opposing to the neo-liberal restructuring of global order?

International labour migration is not a historical novelty, but its unprecedented magnitude and wide geographic dispersion, together with its potential as a force for social transformations in both the societies of origin and those of destination, has led Stephen Castles and Mark J. Miller to predict that the closing years of the twentieth century and the beginning of the twenty-first will be "an age of migration." ${ }^{\prime}$ Within the currently intensified transfers of migrant labourers from developing societies to highly industrialized areas, the Philippines is the largest supplier of governmentsponsored contract labour with over seven hundred thousand workers "deployed" annually to over 160 countries and territories. ${ }^{7}$ Whereas in the early 1970s Philippine migrant labourers were overwhelmingly male and worked in the oil-producing states in the Middle East, their contemporary patterns highly consist of female workers who are mainly destined to other Asian countries. Labour migration in the form of overseas contract work was institutionalized by the Philippine government in 1972 as a stop-gap measure to tackle the persistent problem of unemployment and the lack of foreign exchange. ${ }^{8}$ The remittances from overseas contract workers have become a major source of foreign currency for the national economy. ${ }^{9}$ Based upon a specifically economic calculus and an unquestioned belief in the national development potential of this income stream, the then president of the Philippines, Cory Aquino, called overseas workers "national heroes." 10 In this light, this analysis will stress that these migrant workers are not passive recipients of the Philippine state policies that facilitate overseas employment but are agential political subjects, by arguing that the structured social practices of global labour migrants not only participate in and depend on, but also contest and negotiate, the reconfigurations of labourcapital relations in the (re)constitution of capitalist relations of production and social reproduction within the neo-liberal restructuring of global order.

To systematize this analysis, the section that follows will assess existing approaches to international labour migration, especially paying attention to perhaps the most influential leftist tradition of thought in IR and IPE, neo-Gramscian perspectives that have radically addressed the problem of power dynamics among social forces within capitalist modes of production and enhanced an understanding of the agency/structure relation in the historical transformations of world order. In the next section, the elitist bias of the neo-Gramscian approach will be problematized through perspective of globalization-as-practice, while drawing on emergent literature on the everyday spaces of global political economy. In the concluding section, it will be briefly illustrated how the perception of migrant workers as political actors in the restructuring of the global political economy ontologically and epistemologically questions the traditional notion of "North"-“South" divide.

\section{Power, Production, and Global Labour Migration}

Various orthodox social-scientific disciplines have devised different approaches to the study of international labour migration - broadly categorized into functionalism and structuralism in terms of their appreciations of the relationship between human agency and prevailing socio-economic structures in exploring the question of why people migrate. ${ }^{11}$ However, the gulf between these two paradigms has become 
reified into an unproductive polarization, sustaining a separation between micro and macro scales of analysis and inducing individualistic and structural determinisms. ${ }^{12}$ To more precisely interrogate the complex dynamics of global labour flows, it thus becomes vital to transcend the theoretical impasse that has been created between functionalist and structuralist accounts through reconciling and even transcending the artificially constructed dualism of agencystructure. In this light, the neo-Gramscian approach helps to explore the dialectic relationships between agents and social structures within the reciprocal interactions between rapidly intensified flows of migrant workers and the restructuring in the social relations of production, forms of state, and configurations of power dynamics among various social forces. Although there is no one specific neo-Gramscian approach constructing a cohesive "school"13 and it remains uncertain whether the neo-Gramscians provide a final resolution for the problem of agency-structure that may well prove to be tangled up in a "Gordian knot that cannot be unraveled or solved,"14 their development of a social ontology associated with a distinct notion of "historical structures" contributes to reveal agency within the apparent objective status of social structure.

A neo-Gramscian perspective, first pioneered by Robert W. Cox, has promoted a historicist mode of thought, in contrast to the positivist production of an absolute and transhistorical knowledge based on sets of a priori, ontologically autonomous categories (agents or structures) in mainstream IR and IPE. ${ }^{15}$ By extending Gramsci's approach into the study of global power relations, Cox attempts to rethink a historical materialist problematic of social transformation in world order that revolves around the social ontology of historical structures and to expose the contradictions within it in order to channel structural change in an emancipatory direction. For him, the social ontology of historical structures is conceptualized as "persistent social practices, made by collective human activity and transformed through collective human activity." 16 Put alternatively, it emphasizes historical change as "the reciprocal relationship of structures and actors" 17 within the "limits of the possible" that are not fixed and immutable but exist in the connections between past, present, and future. ${ }^{18}$ Indeed, Cox's formulation of ideas-institutionsmaterial capabilities as social forces operating in the social ontology of historical structures composed of three basic levels - production, forms of state, and world order - makes it possible to explore how structures are socially constructed and consequently become part of the "objective" world by virtue of their existence in the intersubjectivity of various agents. ${ }^{19}$
Within the social ontology of historical structures, Cox underscores the analytical primacy of "the reciprocal relationship between power and production" 20 in the constitution of a normative and material totality of world order. "Production," as he explains, "generates the capacity to exercise power, but power determines the manner in which production takes place." ${ }^{21}$ It is argued that modes of social relations of production are not only confined to everyday conduct entailed in the production and consumption of physical goods but also cover the (re)production of knowledge, morals, and institutions that are required to warrant the hegemony of existing capitalist social order. ${ }^{22}$ Since the 1970s, according to Cox and others, fundamental "structural changes" within the social relations of production have resulted in a crisis of post-war hegemonic world order that crafted a mechanism of reconciling domestic pressures with the requirements of a world economy. ${ }^{23}$ These changes are largely characterized by the internationalization of the state and production through what Cox calls "global perestroika," 24 a political project somehow coordinated by a nébuleuse (an indistinct constellation) of an emerging "transnational managerial class" agency consisting of dominant actors in global capitalism and state officials. ${ }^{25}$ In this vein, the scholars who explicitly and implicitly rely on the neo-Gramscian methods of historicity argue that the contemporary dynamics of global labour migration shape and are shaped by such neo-liberal reconfigurations of the global political economy.

The question of whether the national state still matters in the context of the increasingly globalizing economy has generated controversy among scholars, ranging from some who posit the imminent "retreat of the state" to others who consider the state as one of the main "authors" of globalization. ${ }^{26}$ In this regard, the interactions between migration policies and labour flows not only display the continuing weight of state capacity in regulating the transfers of labour across borders but also underline the qualitatively changing nature and function of the state through "the global process whereby national policies and practices have been adjusted to the exigencies of the world economy" 27 - what Cox calls the "internationalization of the state." ${ }^{28}$ In examining the shifts in immigration policies among OECD member states that have encountered massive inflows of foreign workers, Hélène Pellerin and Henk Overbeek highlight the growing convergence in adopting highly selective and restrictive modes of regulation to manage the logic determining both the instances and places of the mobility-fixity of capital and labour within global capitalism. ${ }^{29}$ On the other hand, in the peripheral societies, as Pellerin notes, "[c] onditions for new credit are generally translated by skewed spending priorities of states and they result in the exclusion of large sections of 
the population." 30 With the prioritization of development strategies in favour of foreign capital through the internationalizing of the state, the outflows of people are perceived as beneficial in bringing foreign currency in the form of remitted wages and in alleviating the employment situation at home. In the case of the Philippines, since the mid-1970s the state has created a policy framework for controlled emigration flows that encourages citizens to seek employment opportunities overseas while forming bilateral agreements with labour-importing countries. ${ }^{31}$

In Cox's view, the internationalizing of the state is intimately associated with the distinctive restructuring of the capitalist world economy expansion, i.e., the "internationalization of production" that denotes "the integration of production processes on a transnational scale, with different phases of a single process being carried out in different countries" and that "currently plays the formative role in relation to the structure of states and world order." 32 The contemporary globalizing of production relations, corresponding with a rise of the structural power of internationally mobile capital, ${ }^{33}$ has spatially rearranged the traditional international division of labour at the global, and more particularly the regional, level leading to the formation of global assembly lines boosting flexible capital accumulation. Pellerin's analysis of the global restructuring of the agro-food industry demonstrates that the introduction of capital-intensive modes of production into peripheral societies has ruined pre-existing socio-economic organization and intensified labour emigration from these societies. ${ }^{34}$ Indeed, the increasing feminization of the new proletariats owing to the recruitment preference at the labour-intensive production plants constructed in the developing regions through the transnational relocation of production has not only disrupted their traditional production and reproduction processes but also contributed to male emigration. ${ }^{35}$ Unstable employment situations in these export-processing zones have also promoted the growing prominence of female emigrants. ${ }^{36}$ Furthermore, as Pellerin notes, a rapid expansion of service industries and the deindustrialization of highly industrialized societies has generated structural shortages of low-wage labour, inducing massive inflows of foreign workers as flexible and "disposable" cheap labour sources. ${ }^{37}$

Thus, the neo-Gramscians' social ontology of historical structure provides an important analytical framework for capturing the interplay of agents and structures, while highlighting dialectical development between global labour displacements and the internationalizing of state and production. From this viewpoint, Pellerin regards transnational migration as a differential agency of change in the world order through the contradictions that its dynamics involve. ${ }^{38}$ However, she together with other neo-Gram- scians does not precisely elaborate the politics of migrant workers, largely due to their concentration on co-operation of, and fractional conflicts within, the transnational managerial class in analyzing the restructuring of the global political economy. Put differently, the questions left out within their work are: how have migrant labourers experienced the implications of the neo-liberal restructuring of the global political economy in their everyday life?; and, how is it possible to understand the viable political agency to promote emancipatory transformations amongst migrant workers that are antagonistic to the dominant global order? In this light, built upon Amoore's conceptualization of globalization as practices, the next section will problematize the silence of neo-Gramscian approach in these regards and, more importantly, attempt to shed light on ways in which the structured social practices of migration workers as agential political actors not only participate in and depend on but also contest and negotiate the reconfigurations of the global political economy.

\section{Globalization-as-Practices and Everyday Spaces: Filipino Migration Workers as Political Subjects}

The conception of the restructuring of world order as a "strategic political project," which characterizes the neoGramscian approach, assumes that globalization is coherently designed and directed by the purposeful and rational actions of individuals and collective agents (transnational managerial class) who are instilled with a unitary identity defined by the shared project itself. Amoore posits that this perspective can provide vital insights "about the elite actors who contribute to a discourse of global restructuring, but little about the everyday forms of thought and action that characterise the nature of that restructuring." ${ }^{39}$ More strikingly, a neo-Gramscian focus on elitist agency presupposes migration workers as passive recipients of state policies and/or as victims of geographically uneven and fragmented development of capitalist economy. It also overestimates the hegemony of transnational capital by diminishing the possibility for transformation within world order, ${ }^{40}$ too often leaving questions regarding counterhegemonic forms of resistance for future research. To critically analyze the potentiality for social change, notes André C. Drainville, it is imperative to "reason from concrete, contingent and situated practices" by seeking "the possibility that the world economy may be a significant context for social forces to meet [and negotiate], where might be defined new modes of social relations." ${ }^{41}$ In this light, Amoore's argument of globalization as structured social practice should be taken seriously to explore ways to articulate the politics of global labour displacements and to view migrant workers as agential political actors. 
The conception of globalization as a political project, as Amoore points out, essentially underestimates the emerging social relations of neo-liberal globalization constituting and shaped by the structured social practices that make these possible. She emphasizes it as key to recognize that neo-liberal restructuring of global political economy is "experienced, given meaning, reinforced/challenged in the everyday social practices of individuals and groups at multiple levels...." 42 By viewing globalization as significantly contested through and contingent upon structured social practices, Amoore argues both that it is the everyday practices of labourers that make particular forms of global production possible and that the restructuring of work potentially may shape contested and contradictory dynamics of social change in the current and future conditions. Such a practice-centred view of global politics calls for bringing workers, including transnational labour migrants, as not passive but rather as agential subjects, into a critical understanding of global political economy. Here, whereas Amoore does not specifically expound the analytical edifices to systematically capture the complexities of practices, Matt Davies and Michael Niemann's engagement with the work of Henri Lefebvre provides useful insights to further elaborate the globalization-as-practices perspective.

Davies and Niemann argue that the addition of Lefebvre's concepts of "everyday life" and "social space" to the analysis of global politics allows for a more comprehensive and more concrete understanding of social practices than much of the work done in IR, by offering a tool to overcome the reification of international relations in social life. ${ }^{43}$ For Lefebvre, "everyday life" is a contested place characterized by mystifications that derive from the experience of alienation in the context of modern society and the struggle to overcome them, while "space" is socially produced as the precondition and the outcome of practices "that permit fresh action to occur, while suggesting others and prohibiting yet others." ${ }^{44}$ By utilizing these conceptualizations, he sees the possibility for emancipatory action in recognizing the contradictions between the actual experience of everyday life and the ideological claims about it, which are mystified through the process of extending abstract space - the space of capitalism, in his view - into all spheres of human life. Derived from Lefebvre's insistence that lived space is a strategic location for social struggle to overcome mystifications, Davies and Niemann stress that "we must account for the waxing and waning of the capacities of specific social agents to effect global politics, and for the circulation of struggles among different actors and between the various levels of social life." 45 They also regard social spaces of family, work, and leisure as crucial arenas in which the emancipatory potential in everyday life can be pursued and international relations be retrieved from the realm of experts and statesmen. In interviewing the Philippine female migrant workers, Pauline Gardiner Barber notes:

... discussion of the contingencies of migration are [sic] set aside through reference to the Filipino cultural idiom of bahala na, which communicates not only a sense of fatalism but also an expression that fate is "in God's hands." By the same token, I also wish to emphasize that fate is negotiated with agency. ${ }^{46}$

In this respect, to highlight Filipino workers as politically agential actors in negotiating their fates and shaping the structures of social and world order, what is crucial is to illustrate global labour migration as practices by concretizing the lived experiences of migrant workers and their struggles within the everyday spaces of family, work, and leisure.

The households' strategic responses to the penetrations of the capitalist social relations of production into the countryside through the neo-liberal economic transformation of the Philippines in part explain the increasing feminization of labour migration since the 1980 s. ${ }^{47}$ Within the contradictory processes of land concentration and land fragmentation through expanded mechanization of agricultural production, Filipino families have tactically centralized marginal landholdings in the hand of sons, while "selecting out" young, single women for migration to cities and urging them to get an education. ${ }^{48}$ Due to unequal gender relations in the Philippines that view female workers as a secondary workforce, as Elizabeth Uy Evita discerns, these women who obtain high education attainment often encounter the conditions of underemployment, which leads them to seek higher-income overseas employment opportunities. ${ }^{49}$ James A. Tyner elucidates by drawing on the work of Jamie Peck that "the lack of opportunities outside the waged labo[u]r system, coupled with limitations within the waged system, contribute to the incorporation of workers into the overseas employment program." 50 Most of the Filipino female migrants who engaged in domestic work abroad, in fact, have an aboveaverage education and many are teachers and nurses. ${ }^{51}$ Such situations where the decisions to obtain overseas contract work have been more progressively prompted by a condition of underemployment rather than unemployment not only problematize the prevailing hypothesis that it is surplus labour that emigrates but also indicate a certain degree of ingenuity and agency of migrant workers in the migratory decision-making processes.

Some studies on Philippine migration also emphasize the importance of obligatory and reciprocal relations within the Filipino family. ${ }^{52}$ Particularly, "[f] or a woman to 
be mindful of well-being of her family, primarily parents but also dependent siblings, fulfils one of the dictates of Philippine femininity." 53 The incentive to become a dutiful daughter by providing "help" to her parents and relatives as remittances therefore may influence the labour migration decision-making process among Filipino women. As women begin to play the role of central breadwinner in their families by means of remittance, they have posed challenges to the historically constructed sexual division of labour in Philippine society. ${ }^{54}$ Furthermore, Tyner presents the narrative of a Filipino migrant who worked in the sex industry in Japan to illustrate how she has obtained a sense of her own independence, both financially and personally, through her experiences of overseas employment. ${ }^{55}$ Nevertheless, Barber more cautiously notes that some women feel liberation from the cultural constrains of marriage, while others find economic gains for their families at the expense of personally fulfilling marital relationships. ${ }^{56}$ Combining these perspectives, therefore, a keen attention must be paid not to essentialize individual Filipinos or the Philippine family in order to precisely capture the agential negotiation of female migrant workers in the social spaces of the family with locally recognized forms of femininity and their complex struggles in the lived experience of overseas employment.

Indeed, to examine the lived experience of Filipino migrant workers in their contested spaces of work, the reformulation of political action as everyday social relations that involve covert and overt (re)negotiation of power in its material and non-material dimensions, rather than only as activities associated with the formal conduct of governance, is important. Christine B.N. Chin's emphasis on the "infrapolitics" of Filipino and Indonesian women who perform commoditized domestic labour in Malaysia provides vital insights in this respect thereby problematizing the socially constructed perception of these women as objects to be controlled and as passive victims powerless to change and challenge employer-employee relations. ${ }^{57}$ "Infrapolitics" refers to the everyday forms of resistance conducted singularly and/or collectively by marginalized or subordinate groups, which are not openly expressed in most cases, largely due to existing power imbalances in most forms of dyadic dominant-subordinate relations, such as that of employer-domestic workers. ${ }^{58}$ Chin sheds light on the infrapolitics of foreign domestic workers by exposing the "hidden" transcripts composed of what these workers say and how they act beyond the realm of the public transcripts in which employers overtly create their superiority within and beyond the workplace. Her analysis of migrant women's narratives on their relationship with employers discerns these workers' rejection of the degree of dehu- manization that inheres in the exchange of domestic work for wages by frequently employing the slave metaphor. In this sense, she advocates that:

If Filipina and Indonesian women's verbal and nonverbal infrapolitical activities are considered within the boundaries of what acts are and are not possible unlegislated work environments that retain the remnants of slavery, then foreign domestic workers are political actors who attempt to renegotiate employeremployee relations in the household in particular, and the Malaysian public's perception of foreign servants in general. ${ }^{59}$

Whereas the effectiveness of foreign domestic servants' infrapolitical activities remains debatable, analysis of these actions highlights the agency of these workers in strategic (re)negotiation with the unequal distribution and exercise of power in the social spaces of their workplace.

Founded upon Lefebvre's argument of the family as the crucial space in which the social relations of production has been (re)produced, the growing participation of migrant women in the commoditized domestic services makes possible the (re)production of social relations of production under the neo-liberal restructuring of the global political economy. The commodification of domestic work not only indicates the deep penetration of the abstract space of market relations into people's everyday life but also disrupts the assumed separation of productive and reproductive spheres that is left unquestioned in much of IR and IPE literature. In Malaysia, as Chin notes, demands for foreign female domestic workers are fuelled by sustained economic development that enlarged the middle class, while providing greater employment opportunities for, and heightening the job expectations of, working class Malaysian women. ${ }^{60}$ Here, Brigitte Young sheds light on the link between the feminization of work and the increasing polarization or segmentation among women, especially in the highly industrialized societies. She argues that the contemporary reorganization of the international division of labour in the decentralized "flexible accumulation" processes ${ }^{61}$ of the global economy involves the emergence of the new "mistress" and her "maid." The growing participation of professional women in the labour market is accompanied by the development of paid work in the private sphere of family, which allows these women to rely on other women, often foreign migrant women, in order to cope with the increasingly reprivatized housework. This formation of a new power relationship between women through the marketization of household-oriented services, as Young warns, has led to the creation of "a new ethnically defined female underclass that lacks political rights and legal rights." 62 That is, to concretely explore the dynamics of work spaces that 
female domestic worker are involved in, the contextualization of their lived experience needs to take into account these processes of the feminization of work and the concomitant reprivatization of household work and their implications for creating the heterogeneity of the category "woman" in terms of class, gender, and ethnicity.

In terms of the social space of leisure, as Lefebvre contends, leisure provides compensation for the alienation of work inasmuch as it offers the possibility of pleasure, but its time and space are not uncontested, where alienation also takes place. ${ }^{63}$ The spaces of leisure for Filipino migrant workers, especially female domestic servants, are highly circumscribed. On their limited days off the most common places which Philippine female domestic workers occupy are shopping centers. ${ }^{64}$ Although the analysis does not clarify whether these women actually purchase goods and/or services there, the production of migrant workers in the Philippines and the exchange of their labour power in the global labour market are closely interrelated with the encouragement of consumerism. In fact, routinely published advertisements in Philippine newspapers and magazines have extolled the material benefits of oversea employment by showing returning migrant workers laden with consumer goods. ${ }^{65}$ The enhanced consumption practices in the Philippines through the escalation of international labour migration are also reflected in the dispersal of overseas remittance incomes to small-scale "unproductive" investments, which has created the effect of increasing social and economic polarization at the village level. ${ }^{66}$ Overall, as the general need for leisure finds expression as consumerism, people encounter leisure not as the avenue through which they can obtain compensation for the fragmentation and alienation of work but rather as the further alienating spaces predetermined by the need to accelerate the circulation of commodities. ${ }^{67}$

In contrast, Katherine Gibson et al. illustrate how the Asian Migrant Center (AMC) in Hong Kong creates the social space of leisure in which the empowering process for the Filipino migrant women are empowered to effect changes in social, economic, and political structures while promoting "development" not necessarily defined in the capitalist mould in their "home" communities. ${ }^{68}$ The AMC encourages migrant women to participate in its training modules in their leisure time in order to acquire new entrepreneurial capacities and skills. These female migrants are also assisted in obtaining the capacity to manage hardearned wages in their absence and not to depend on husbands or other family members. In other words, the strategies pursued by the AMC not only show how the Filipina migrant contract domestic workers are potentially progressive economic activists but also highlight the mul- tiple and interdependent class subjectivities open to these workers. One of the most clearly advocated critiques of the AMC's program points to its possibility of inducing returning migrants to become capitalists, whereby fortifying the bourgeois nature of Philippine society and accelerating its incorporation into a global capitalist system. However, such a viewpoint, as Gibson et al. claim, reduces all happenings that occur in the period of global capitalism to indication of the hegemonic power of capitalism. These authors underline the importance of de-linking analysis from any notion of historical necessity or homogeneity within a static and teleological framework, while stressing the AMC's efforts as liberating migrant workers and complexifying futures.

Thus, the exploration of the lived experience of Filipino migrant workers and their struggle in the social spaces of family, work, and leisure shows how these workers are contradictorily complicit but at the same time opposing to the neo-liberal restructuring of the global political economy. Nevertheless, these existing studies focus on the specific collective and/or individual actions by the specific types of Filipino workers, such as female domestic workers, in the confined space and time. Future studies are recommended to overcome this limitation in order to more holistically analyze the dynamics of migrant workers' everyday spaces. In this vein, what is the most crucial to keep in mind is, as Davies and Niemann precisely put it, to realize that "the possibility for emancipatory action lies in the possibilities of differential spaces, where we recognize difference and thus oppose the homogenization of abstract space [of capitalism].”69

\section{Concluding Remarks}

Reflecting the current dynamics of global labour migration, the prevailing fascination with the elites in the field of IR and IPE, which is exemplified by neo-Gramscian perspectives, denies the agency of migrant workers and obscures the complexity of their lived experience. In this regard, Amoore's globalization-as-practices facilitates the concretization of the contingent and situated processes of international labour migrations. Founded upon this framework while referring to Davies and Niemann's rethinking of Lefebvre's work, this essay emphasizes migrant workers as political subjects who are contradictorily complicit in and yet opposed to the neo-liberal restructuring of the global political economy. By particularly focusing on the practices of Philippine migrant workers, it demonstrates how their struggles within the everyday spaces of family, work, and leisure not only participate in and depend on but also challenge and (re)negotiate the neo-liberal transformations of the global political economy. Further, such a perception of 
global labour migration problematizes the traditional divide between "North" and "South" in the ontological and epistemological senses. In the Philippines, with the largest flows of overseas contract workers in the global economy, transnational experiences are "localized" through the anticipation of departures and the enthusiasm created by returning migrants. Circular flows of people, information, materials, and cash produce an imaginative, new form of "place" that stretches across national boundaries as well as core-peripheral and rural-urban distinctions by making it difficult to believe in the "magic of straight lines"70 that ontologically differentiate the "North" and "South." On the other hand, the emphasis of Filipino migrant workers as agential political actors poses serious challenge to the myth in the dominant study of IR that locates the subject that speaks through production of universal, theoretical knowledge only in the "North," while viewing the subject in the "South" as the provider of empirical data. To overcome this epistemological presumption, as Ramón Grosfoguel reminds us,

Critical border thinking... redefines modernity from the cosmologies and epistemologies of the subaltern, located in the oppressed and exploited side of the colonial difference.... [Only such a perspective makes possible] a redefinition of citizenship, democracy, human rights, and humanity, beyond the narrow definitions imposed by European modernity. ${ }^{71}$

\section{Notes}

1. Louise Amoore, Globalisation Contested: An International Political Economy of Work (Manchester and New York: Manchester University Press, 2002), 7.

2. E.g, André C. Drainville, Contested Globalization: Space and Place in the World Economy (London and New York: Routledge, 2004).

3. For the critical study of the problems in the concept of "global civil society," see Mustapha Kamal Pasha and David L. Blaney, "Elusive Paradise: The Promise and Peril of Global Civil Society,” Alternatives 23, no. 3 (1998): 417-450; Louise Amoore and Paul Langley, "Ambiguities of Global Civil Society," Review of International Studies 30, no. 1 (2004): 89-110. Also, see Edward A. Comor, "The Role of Communication in Global Civil Society: Forces, Processes, Prospects," International Studies Quarterly 45, no. 3 (September 2001): 389-408, on the important account of the concept of global civil society through the lens of the critical political economy of international communication.

4. Matt Davies and Michael Niemann, "The Everyday Spaces of Global Politics: Work, Leisure, Family," New Political Economy 24, no. 4 (2002), 557.

5. E.g. ibid. and Drainville.
6. Stephen Castles and Mark J. Miller, The Age of Migration: International Population Movements in the Modern World, 2nd ed. (New York and London: Gulford Press, 1998).

7. James A. Tyner, Made in the Philippines: Gendered Discourses and the Making of Migrants (London and New York: Routledge, 2004), 21. This number does not include approximately 1.9 million Filipinos living abroad with "unauthorized" status. Furthermore, according to Kanlungan Centre Foundation in the Philippines, the estimate 7.29 million overseas Filipino workers - both sea- and land-based - are spread out in more than 180 countries and destinations, which constitute over 10 per cent of the country's population and at least a fifth of its labour force. Kanlungan Centre Foundation, Fast Facts on Filipino Labor Migration 2000 (Quezon City: Kanlungan Centre Foundation Inc., 2000); quoted in Mary Lou L. Alcid, "Overseas Filipino Workers: Sacrificial Lambs at the Altar of Deregulation," in International Migration and Sending Countries: Perceptions, Policies and Transnational Relations, ed. Eva Østergaard-Nielsen (New York: Palgrave Macmillan, 2003), 99.

8. For a detail review of this history, see Joaquin L. Gonzalez III, Philippine Labour Migration: Critical Dimensions of Public Policy (Singapore: Institute of Southeast Asian Studies, 1998).

9. The annual average of remittance was US $\$ 6.5$ billion from 1999 to 2001, which is the single biggest source of foreign currency for the Philippines; see Alcid, 100. Indeed, for 2003, remittance totalled US $\$ 7.6$ billion, accounting for 7.5 per cent of the GDP; see Asian Migrant Yearbook 2004: Migration Facts, Analysis and Issues in 2003 (Hong Kong: Asian Migrant Centre [AMC], 2004), 249.

10. Katherine Gibson et al., "Beyond Heroes and Victims: Filipina Contract Migrants, Economic Activism and Class Transformations," International Feminist Journal of Politics 3, no. 3 (Autumn 2001): 367.

11. Caroline B. Brettell and James F. Hollifield point out, in the study of international migration, a deep separation of those social scientists who take a top-down "macro" approach from those whose approach is bottom-up "micro" oriented. Caroline B. Brettell and James F. Hollifield, "Migration Theory: Talking across Disciplines," in Migration Theory: Talking across Disciplines, eds. Caroline B. Brettell and James F. Hollifield (New York and London: Routledge, 2000), 2. Also, the broad review of existing different theories of international labour migration, see Douglas S. Massey et al., "Theories of International Migration: A Review and Appraisal," Population and Development Review 19, no. 3 (September 1993): 431-466.

12. Jon Goss and Bruce Lindquist, "Conceptualizing International Labor Migration: A Structuration Perspective," International Migration Review 29, no. 2 (Summer 1995): 318.

13. Andreas Bieler and Adam David Morton, "Introduction: NeoGramscian Perspectives in International Political Economy and the Relevance to European Integration," in Social Forces in the Making of the New Europe: The Restructuring of European Social Relations in the Global Political Economy, ed. Andreas Bieler and Adam David Morton (New York: Palgrave, 2001), 
6, 17. Also, Adam David Morton, "The Sociology of Theorizing and Neo-Gramscian Perspectives: The Problems of 'School' Formation in IPE,' in Social Forces in the Making of the New Europe: The Restructuring of European Social Relations in the Global Political Economy, ed. Andreas Bieler and Adam David Morton (New York: Palgrave, 2001), 25-43. Stephen Gill addresses the same point much earlier by noting that: "As there is no single school of Marxism...so too is there no single Gramscian or 'Italian' school." Stephen Gill, "Gramsci and Global Politics: Towards a Post-Hegemonic Research Agenda," in Gramsci, Historical Materialism and International Relations, ed. Stephen Gill (Cambridge: Cambridge University Press, 1993), 2. For the variety of neo-Gramscian perspectives dealing with a diversity of issues, see Adam David Morton, "Social Forces in the Struggle over Hegemony: Neo-Gramscian Perspectives in International Political Economy," Rethinking Marxism 15, no. 2 (April 2003): 165-67; and Morton, "The Sociology of Theorizing and Neo-Gramscian Perspectives," 37-41.

14. Andreas Bieler and Adam David Morton, "The Gordian Knot of Agency-Structure in International Relations: A Neo-Gramscian Perspective," European Journal of International Relations 7, no. 1 (2001): 5-35.

15. E.g. Robert W. Cox, "Social Forces, States, and World Orders: Beyond International Relations Theory," in Approaches to World Order, ed. Robert W. Cox with Timothy J. Sinclair (Cambridge: Cambridge University Press, 1981/1996), 85-123; and Robert W. Cox, Production, Power, and World Order: Social Forces in the Making of History, vol.1, Power and Production (New York: Columbia University Press, 1987).

16. Cox, Production, Power, and World Order, 4.

17. Cox, "Critical Political Economy," in International Political Economy: Understanding Global Disorder, ed. Björn Hettne (London: Zed Books, 1995), 33.

18. Gill, "Gramsci and Global Politics," 8-9; and, Gill, "Epistemology, Ontology and the 'Italian School,"' in Gramsci, Historical Materialism and International Relations, ed. Stephen Gill (Cambridge: Cambridge University Press, 1993), 22.

19. According to Cox, (1) the social relations of production, encompassing the totality of social relations in material, institutional, and discursive forms that engender particular social forces; (2) forms of state, articulating the historically contingent state/civil society complexes; and (3) world order, as the ensemble of power among diversified social forces which not only represent persistent patterns of stability and conflict but also permit scope for thinking about how alternative forms of world order might emerge. Cox, "Social Forces, States, and World Orders: Beyond International Relations Theory," 97-101. More recently, Isabella Bakker and Stephen Gill consider Cox's triadic formation of human activity "not as levels as [he suggests], but as different moments in the constitution of a contradictory totality of world order." Isabella Bakker and Stephen Gill, "Ontology, Method, and Hypotheses," in Power, Production and Social Reproduction: Human In/security in the Global Po- litical Economy, ed. Isabella Bakker and Stephen Gill (New York: Palgrave Macmillan, 2003), 25.

20. Cox, Production, Power, and World Order, 1.

21. Ibid.

22. Cox, "Production, the State and Change in World Order," in Global Changes and Theoretical Challenges: Approaches to World Politics for the 1990s, ed. Ernst-Otto Czempiel and James N. Rosenau (Lexington, MA: Lexington Book, 1989), 39; quoted in Bieler and Morton, "The Gordian Knot of AgencyStructure in International Relations," 24.

23. E.g. Cox, "Global Perestroika"; Cox, "Social Forces, States and World Orders"; and Gill, "Gramsci and Global Politics."

24. Cox, "Global Perestroika."

25. Cox, "Social Forces, States and World Order," 111. For the critical discussion regarding the idea of "nébuleuse," see Drainville, "Of Social Spaces, Citizenship, and the Nature of Power in the World Economy," Alternatives 20 (1995): 51-79. Here, it may be argued that the neo-Gramscian view of the neoliberal restructuring of the global political economy as political project is derived from Karl Polanyi's analysis of the deliberate construction of liberal economy as a utopian model in the nineteenth century by the state officials. Karl Polanyi, The Great Transformation: The Political and Economic Origins of Our Time (Boston: Beacon Press, [1944] 1957).

26. Susan Strange, The Retreat of the State: The Diffusion of Power in the World Economy (Cambridge and New York: Cambridge University Press, 1996); Leo Panitch, "Globalization and the State," Socialist Register: Between Globalism and Nationalism, eds. Leo Panitch and Ralph Miliband (London: Merlin Press, 1994), 60-93; and Panitch, "Rethinking the Role of the State in an Era of Globalization," in Globalization: Critical Reflections, ed. James H. Mittelman (London and Boulder, CO: Lynne Rienner Publishers, 1997), 83-113.

27. Cox, Production, Power, and World Order, 253.

28. Ibid., 253-65. Also, see Cox, "Social Forces, States and World Orders," 230-32. For a similar but competing interpretation of the "internationalization of the state," see Sol Picciotto, "The Internationalization of the State," Capital and Class 43 (Spring 1991): 43-63.

29. Hélène Pellerin and Henk Overbeek, "Neo-Liberal Regionalism and the Management of People's Mobility," in Social Forces in the Making of the New Europe: The Restructuring of European Social Relations in the Global Political Economy, ed. Andreas Bieler and Adam David Morton, foreword by Robert W. Cox (New York: Palgrave, 2001), 137-157.

30. Hélène Pellerin, "New Global Migration Dynamics," in Globalization, Democratization and Multilateralism, ed. Stephen Gill (New York: St. Martin's Press, 1997), 111.

31. Gonzalez III, 33-36.

32. Cox, "Social Forces, States and World Orders," 109.

33. Stephen Gill and David Law, "Global Hegemony and the Structural Power of Capital," International Studies Quarterly 33, no. 4 (1989): 484.

34. Pellerin, 115-16. 
35. E.g. Jean L. Pyle, "Sex, Maids, and Export Processing: Risks and Reasons for Gendered Production Networks," International Journal of Politics, Culture and Society 15, no. 1 (September 2001): 55-76.

36. For the case of the U.S. immigration, see Saskia Sassen, Globalization and Its Discontents: Essay on the New Mobility of People and Money (New York: New Press, 1998).

37. Pellerin, 112-13.

38. Ibid., 122.

39. Amoore, Globalization Contested, 6.

40. Drainville, "Of Social Spaces, Citizenship, and the Nature of Power in the World Economy."

41. Drainville, Contesting Globalization, 32, 30.

42. Amoore, Globalization Contested, 7. Also, see Paul Langley, "The Everyday Life of Global Finance," IPEG Papers in Global Political Economy 5 (February/March 2003), http://www.bisa. ac.uk/groups/ipeg/papers/PaulLangley.pdf (accessed April 14, 2005).

43. Davies and Niemann.

44. Ibid., 559, quoting Henri Lefebvre, The Production of Space (Oxford: Blackwell, 1991), 73

45. Davies and Niemann, 567.

46. Pauline Gardiner Barber, "Agency in Philippine Women's Labour Migration and Provisional Diaspora," Women's Studies International Forum 23, no. 4 (2000): 403.

47. In 1987, women comprised 47 per cent of land-based overseas worker. As of July 2002 they constituted 73 per cent of annual contract labour deployment of land-based workers. POEA, "Deployment of Land-Based Newly Hired Overseas Filipino Sorkers by Skills, Category and Sex," <http://www.poea. gov.ph $>$; quoted in Alcid, 103.

48. Elizabeth Uy Eviota, The Political Economy of Gender: Women and the Sexual Division of Labour in the Philippines (London and Atlantic Highlands, NJ: Zed Books, 1992).

49. Ibid., 90-94.

50. Tyner, 77.

51. Eviota, 144.

52. Tyner, 116-17.

53. Barber, 402 .

54. Eviota, 145.

55. Tyner, esp. chap. 5.

56. Barber, 405.
57. Christine B.N. Chin, In Service and Servitude: Foreign Female Domestic Workers and the Malaysian "Modernity" Project (New York: Columbia University Press, 1998).

58. James C. Scott, Domination and the Arts of Resistance: Hidden Transcripts (New Haven: Yale University Press, 1990). Also see James C. Scott, Weapons of the Weak: Everyday Forms of Peasant Resistance (New Haven: Yale University Press, 1985).

59. Chin, 163.

60. Ibid., 353.

61. David Harvey, The Conditionality of Postmodernity (Oxford: Blackwell, 1989); quoted in Brigitte Young, "The 'Mistress' and the 'Maid' in the Globalized Economy," in Working Classes, Global Realities: Socialist Register 2001, ed. Leo Panitch and Colin Leys (London: Merlin Press, 2000), 316.

62. Young, 322.

63. Davies and Niemann, 571.

64. Brenda S.A. Yeoh and Shirlena Huang, "Spaces at the Margins: Migrant Domestic Workers and the Development of Civil Society in Singapore," Environment and Planning A 31 (1999): 1149-67.

65. Tyner, 62.

66. Gibson et al., 369.

67. Davies and Niemann, 572.

68. Gibson et al., 380.

69. Davies and Niemann, 575.

70. R.B.J. Walker, After the Global/Before the World (Cambridge: Cambridge University Press, forthcoming), 63; quoted in Naeem Inayatullah and David L. Blaney, International Relations and the Problem of Difference (New York and London: Routledge, 2004), 187.

71. Ramón Grosfoguel, "The Implications of Subaltern Epistemologies for Global Capitalism: Transmodernity, Border Thinking, and Global Coloniality," in Critical Globalization Studies, ed. Richard P. Appelbaum and William I. Robinson (New York and London: Routledge, 2005), 288. Also, see Mustapha Kamal Pasha, "Islam, 'Soft' Orientalism and Hegemony: A Gramscian Rereading," Critical Review of International Studies and Political Philosophy 8, no. 4 (December 2005): 543-58.

Hironori Onuki is a Ph.D. candidate in Political Science at York University, Toronto, and a graduate associate of York Centre for Asian Research at York University. 